\title{
CARDIAC ELECTROPHYSIOLOGY CLINICS
}

\section{FORTHCOMING ISSUES}

March 2018

Contemporary Issues in Patients with Implantable Devices

Raymond Yee, Mark Link, and Amin Al-Ahmad, Editors

\section{June 2018}

Clinical Arrhythmias: Bradicardias, Complex Tachycardias and Particular Situations: Part II Luigi Padeletti and Giuseppe Bagliani, Editors

\section{September 2018}

Lead Management for Electrophysiologists

Noel G. Boyle and Bruce Wilkoff, Editors

\section{RECENT ISSUES}

September 2017

Normal Electrophysiology, Substrates, and the Electrocardiographic Diagnosis of Cardiac Arrhythmias: Part I

Luigi Padeletti and Giuseppe Bagliani, Editors

\section{June 2017}

Cardiac Arrhythmias in Adults with

Congenital Heart Disease

Seshadri Balaji, Ravi Mandapati, and Kalyanam Shivkumar, Editors

March 2017

Ventricular Tachycardia in Structural Heart Disease

Amin Al-Ahmad and Francis E. Marchlinski, Editors

\section{ISSUE OF RELATED INTEREST \\ Clinics in Sports Medicine, July 2015 (Vol. 34, No. 3) \\ Sports Cardiology \\ Robert W. Battle, Editor \\ Available at: http://www.sportsmed.theclinics.com}

\section{THE CLINICS ARE AVAILABLE ONLINE!}

Access your subscription at: 